\title{
Magmatic vs. hydrothermal origin of fluorites from Vlastějovice, Bohemian Massif
}

\author{
Magmatický vs. hydrotermální vznik fluoritů z Vlastějovic, Český masiv
}

(4 figs, 1 tab.)

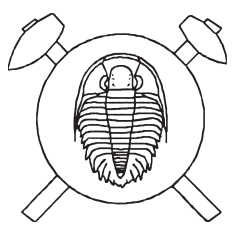

\author{
LUKÁŠ ACKERMAN
}

Institute of Geochemistry, Mineralogy and Mineral Resources, Charles University, Albertov 6, 128 43, Praha 2, Czech Republic Institute of Geology, Academy of Sciences of the Czech Republic, Rozvojová 135, 165 02, Praha 6, Czech Republic; ackerman@gli.cas.cz

\begin{abstract}
Several aspects of fluorite mineralization in barren pegmatites are studied and discussed in order to explain their magmatic or hydrothermal origin. The barren pegmatites are intruded in skarns at Vlastějovice in the northern part of the Moldanubian Zone. Abundant violet to colourless fluorite with hornblende and garnet were formed during pegmatite contamination by the country-rock skarn. The process included import of calcium and fluorine from the skarn body and formation of reaction zones along the pegmatite margins. Optical microscopy and cathodoluminiscence study show that fluorites are very homogeneous, without any visible growth zones. The REE patterns show a strong HREE depletion in fluorites from contact zones in contrast to those from central zones of pegmatites. The HREE contents in fluorite from contact zones are interpreted as a result of REE diffusion between fluorite and garnet at high temperatures. Pseudosecondary fluid inclusions found in fluorite (FS1) probably represent evolved primary pegmatitic fluid saturated by calcium $\left(\mathrm{CO}_{2}\right.$ loss followed by calcite precipitation) at the pegmatites margins. Minimal temperature of fluorite crystallization can be estimated from the homogenization temperature of early pseudosecondary inclusions (FS1A: $308-372{ }^{\circ} \mathrm{C}$ ). Thus, we can assume, that fluorites probably formed during the late stages of pegmatite consolidation under magmatic-hydrothermal transition conditions.
\end{abstract}

Key words: fluorite; pegmatites; skarn; REE; cathodoluminiscence

\section{Introduction}

Fluorite mineralizations have been described from various parts of the Bohemian Massif. They typically represent low-temperature hydrothermal veins with barite or quartz of a variable age (Variscan to Quaternary, e.g., Kämpf - Kuschka 1989, Chrt 1988, Bernard 1991). In contrast, fluorite mineralization related to pegmatites intruded in skarn bodies has a different position, mineralogical association and probably a different age and temperature of implacement. Fluorite is a characteristic mineral of barren pegmatites, which crosscut skarns in various geological units of the Bohemian Massif (e.g., Vlastějovice, Líšná, Domanínek). Pegmatites in these settings exhibit extensive endocontact reaction zones along dyke margins, which document a strong contamination by skarn. These zones contain variable amounts of garnet (grossular-andradite), Ca-hornblende, titanite, allanite and enormous quantities of fluorite (up to 30 vol. \%) in contrast to their occurence in the inner zones of pegmatites. High concentrations of $\mathrm{H}_{2} \mathrm{O}$ (up to 1.72 wt. \%) and $\mathrm{F}$ (up to 0.72 wt. \%) were described from hornblende (Žáček - Povondra 1991) and titanite - 0.74 wt. \% and 1.59 wt. \%, respectively (Mrázek - Vrána 1985). The presence of fluorite and allanite strongly correlates with the presence of garnet and hornblende and thus with contamination processes. In contrast to these facts, fluorites have usually been explained as a product of later hydrothermal processes, without any connection to pegmatite melts (e.g., Staněk 1976).

The studied fluorites were sampled from the barren pegmatites, that cross-cut magnetite-bearing skarn body in the northern part of the Moldanubian Zone near Vlastě- jovice nad Sázavou village (Fig. 1). This paper presents geochemical data, fluid inclusion measurements and luminiscence properties of fluorite. The information is used for discussion and interpretation of its magmatic or hydrothermal origin.

\section{Geology of the study area}

The fluorite-bearing pegmatites intruded skarn bodies in the Variegated Group of the Moldanubian Zone. This unit comprises metasedimentary gneisses with numerous lenses of skarn, amfibolite, quartzite and eclogite (e.g., Koutek 1950, Klečka et al. 1992) (Fig. 1).

Skarns form lenticular bodies up to $\mathrm{X} 0 \mathrm{~m}$ thick and $\mathrm{X} 00 \mathrm{~m}$ long, conformable to foliation of surrounding metasedimentary gneisses. Garnet-pyroxene skarn forms central parts of the skarn bodies, while epidote- and/or hornblende-rich garnet \pm pyroxene skarns are common on the periphery (Potužák 1996). The garnet composition is highly variable in contrast to very homogeneous pyroxene of hedenbergite composition. Žáček (1997) identified five generations of garnets: the older generations (I-III) are of grossular-andradite composition with up to 1.2 and 1.18 wt. $\% \mathrm{H}_{2} \mathrm{O}$ and $\mathrm{F}$, respectively; the younger generations (IV-V) are of grossular-almandine composition (free of $\mathrm{H}_{2} \mathrm{O}$ and $\mathrm{F}$ ). Two hypothesis for the skarns origin are currently discussed: (i) contact metamorphism of carbonates by granitoids (Koutek 1950, Němec 1996, Žáček 1997) or (ii) regional metamorphism of iron-bearing sedimentary/sedimentary-exhalative layers (Potužák 1996, Pertold et al. 1997).

The granitic barren pegmatites with fluorite at Vlastějovice are absent from the country-rock two-mica gneiss 

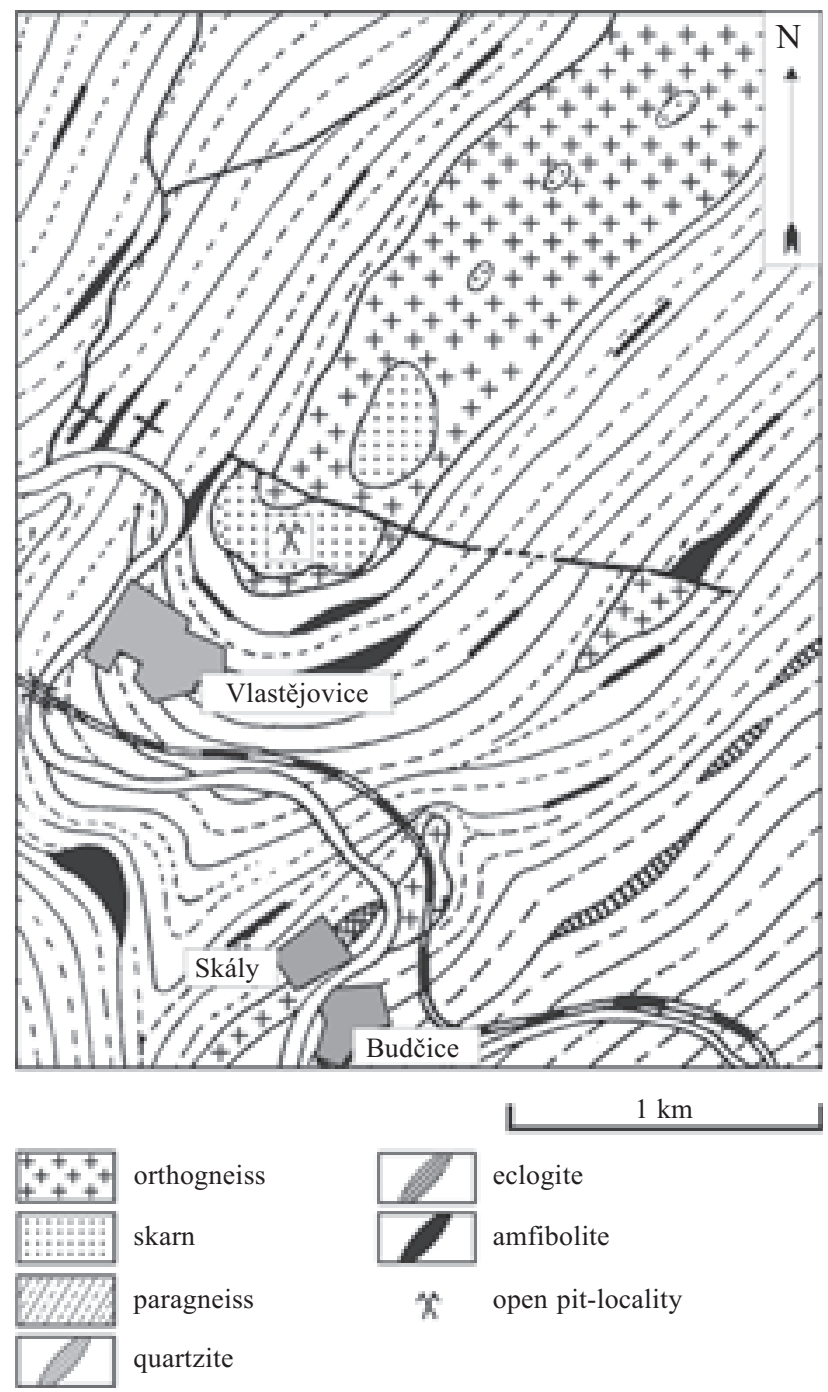

Fig. 1. Geological map of the Vlastějovice area (modified after Koutek, 1950).

unit. In addition to pegmatites, numerous hydrothermal veins (clinopyroxene veins, low-temperature quartz-carbonate veins, veins with Sb-mineralization) penetrated the skarn bodies (e.g., Žáček 1985, Žáček - Povondra 1991, Brabec 2002).

\section{Pegmatites}

Three types of pegmatites were identified in the Vlastějovice area on the basis of their mineralogy and texture: (i) barren pegmatites, (ii) rare-element LCT pegmatite of the elbaite subtype and (iii) U-Th (Ti-Zr-Nb-Ta) pegmatites.

The barren pegmatites are predominant. They form small-size dykes usually from 0.2 to $0.6 \mathrm{~m}$ wide, with mostly subvertical orientation. Their mineralogy is simple: plagioclase $\left(\mathrm{Ab}_{63-100} \mathrm{An}_{0-35} \mathrm{Or}_{0-2}\right)$ and microcline $\left(\mathrm{Ab}_{0-19}\right.$ $\left.\mathrm{An}_{0-1} \mathrm{Or}_{80-97}\right)$ in variable proportions, with quartz. Accessories are represented by allanite, titanite and fluorite. Reaction endocontact zones along the dyke margins contain garnet, Ca-hornblende, titanite and fluorite with subor- dinary feldspars and quartz. The presence of these zones suggests a low temperature gradient between pegmatitic melt and skarn during emplacement of the pegmatite bodies.

Only a single dyke of the rare-element LCT pegmatite has been found in the late 80 s and described by Čech (1985). According to his description, the dyke was of irregular shape with complex internal structure: (i) a coarse-grained zone of plagioclase-quartz with a common presence of tourmaline (schorl) and rare biotite and fluorite in the endocontact zones; (ii) a fine-grained zone with graphic intergrowths of plagioclase and quartz; and (iii) a blocky K-feldspar zone with tourmalines (schorl to elbaite). Accessories found in this zone of the lithium pegmatite include bavenite, danburite, datolite, pyrochlore, bismuth-pyrochlore, magnetite and Mn-columbite (Čech 1985, Novák - Povondra 1995, Novák - Černý 1998). Plagioclase exhibits oligoclase composition $\left(\mathrm{Ab}_{75-80}\right.$ $\mathrm{An}_{20-23} \mathrm{Or}_{0-2}$ ), K-feldspar has composition $\mathrm{Ab}_{7-11} \mathrm{An}_{0} \mathrm{Or}_{88-93}$.

The U-Th (Ti-Zr-Nb-Ta) pegmatites form sparse dykes up to a few metres wide, without any zoning, except reaction zones (Žáček 1985). Basic mineralogy and texture is identical to the barren dykes, but accessory uraninite, thorite, anatase, pyrochlore and rare sulphides have been identified by Rezek - Kryst (1985).

$\mathrm{P}-\mathrm{T}$ conditions of barren pegmatites and rare-element LCT pegmatite were estimated to $550-640{ }^{\circ} \mathrm{C}(450-680$ $\mathrm{MPa})$ and $500-560^{\circ} \mathrm{C}(430-530 \mathrm{MPa})$ respectively. The fluids assocciated with the melts of barren and rare-element pegmatite are represented by $\mathrm{H}_{2} \mathrm{O}-\mathrm{CO}_{2}-\mathrm{NaCl}$ and $\mathrm{H}_{2} \mathrm{O}-\mathrm{CO}_{2} / \mathrm{N}_{2}-\mathrm{H}_{3} \mathrm{BO}_{3}-\mathrm{NaCl}$, respectively (Ackerman 2004, Ackerman et al. 2005).

\section{Analytical methods}

The trace elements in fluorite and titanite were analysed by long-term thermal instrumental neutron activation analyses (INAA) at the Ecole des Mines de Paris (France).

Cold-type cathodoluminiscence (CLL 8200 MK4) coupled with optical microscope was used to study fluorite luminiscence. The working conditions were $13-18 \mathrm{kV}$ accelerating voltage and 500-600 $\mu \mathrm{A}$ current.

Microthermometric measurements of the fluid inclusions in fluorite were carried out on two samples using the Linkam THMSG 600 stage mounted on the Olympus BX 50 microscope. The criteria of Roedder (1984) were used for the discrimination between primary, pseudosecondary and secondary inclusions. The stage was calibrated at $-56.6,0,+31,125$ and $304{ }^{\circ} \mathrm{C}$ at the beginning and the end of the fluid inclusion study. The following temperatures of phase changes were measured: last ice melting (Tm-ice) and the total inclusion homogenization (Th-tot). The degree of fill was estimated visually as the $\mathrm{L} /(\mathrm{L}+\mathrm{V}+\mathrm{S})$ volume ratio. The salinity of the aqueous phase is always expressed as wt. $\% \mathrm{NaCl}$ eq. using equation of Bodnar (1993). 
Raman spectra of the fluid inclusions were collected using the $632.8 \mathrm{~nm}$ monochromatic laser with $2 \mathrm{~mW}$ energy at the University of Porto. The system was connected with optical microscope and high-resolution CCD camera. The acquisition time for each spectrum was 20 seconds.

\section{Fluorites}

\section{Texture}

The colour of fluorite is highly variable, mostly purple to pink, but also black in the presence of allanite. Fluorite fills irregular pockets ( $\mathrm{mm}$ to $\mathrm{cm}$ size range) in the coarse-grained matrix (garnet-hornblende-feldsparsquartz) and forms intimate intergrowths (graphic-like texture) with other minerals in reaction zones of barren pegmatites, e.g., garnet, plagioclase, quartz, or inclusions in these minerals. Grains have sharp-edge shape, which is probably consequance of a strong brecciation processes followed by formation of fractures ( $\mathrm{mm}$ in size) between grains and filled by carbonate (Fig. 2a). Also, numerous tiny fractures, only up to $0.1 \mathrm{~mm}$ wide and filled by calcite, can be observed in fluorite under polarized light, but not in other associated minerals. The fracture-surfaces of fluorite show commonly etch features - a partial dissolution of fluorite possibly associated with calcite precipitation. Euhedral (hexahedron) crystals and growth zones were not observed under polarized light.

\section{Luminiscence}

Variable thermoluminiscence and UV luminiscence of fluorites from the Vlastějovice was first described by Vavř́n $(1960,1962)$, who considered these properties due to increased concentrations of $\mathrm{Y}, \mathrm{Yb}$ and $\mathrm{Mn}$. However, the new analyses show that concentrations of these elements are very low (Table 1).
The cathodoluminiscence of fluorites is blue-violet without any indication of growth zones, which is very well developed in a hydrothermal fluorite from the Brno Massif (Dolníček - Slobodník 2001). However, the fluorites exhibit green-blue luminiscence centers, which probably represent crystallization cores of the fluorites (Fig. 2b). Strong blue cathodoluminiscence of hydrothermal fluorites as a result of high Eu concentration was described by Ogola et al. (1994). Calcite filling fractures between fluorite grains has orange luminiscence without growth zones.

\section{Rare-earth element geochemistry}

The total analysed REE content (mostly without Pr, Dy, Er and Tm; Table 1) in fluorites from central zones and reaction zones of the pegmatites strongly vary from 25 to $464 \mathrm{ppm}$ and 1 to $5 \mathrm{ppm}$, respectively. Therefore, fluorites from the central zones are strongly REE enriched in contrast to fluorites from contact zones of pegmatites. As indicated by $\mathrm{La} / \mathrm{Yb}$ ratio, apart from two samples, all fluorites are enriched in LREE. Samples from the central zones of pegmatites exhibit lower $\mathrm{La} / \mathrm{Yb}(0.1-14.2)$ and negative Eu anomaly in contrast to fluorites from contact zones with $\mathrm{La} / \mathrm{Yb}=50.7-82.6$ and positive $\mathrm{Eu}$ anomaly. Thus, fluorites from contact zones are strongly HREE depleted (Fig. 3). The HREE depletion is a probable consequence of fluorite equilibration with a mineral strongly fractionating HREE (probably garnet) in reaction zones. Similar REE patterns are also characteristic for titanites. Besides this, fluorites from central zones are enriched in $\mathrm{Na}$ and $\mathrm{W}$, but $\mathrm{Sr}$ depleted in contrast to fluorites from reaction zones. Different stabilities of the REE-F complexes cause lower Tb/La of early-formed fluorite. As crystallization proceeded, fluorine concentration in fluid rapidly decreased, followed by decomposition of $\mathrm{TbF}^{+}$and other rare earth-fluorine complexes. Thus, late-
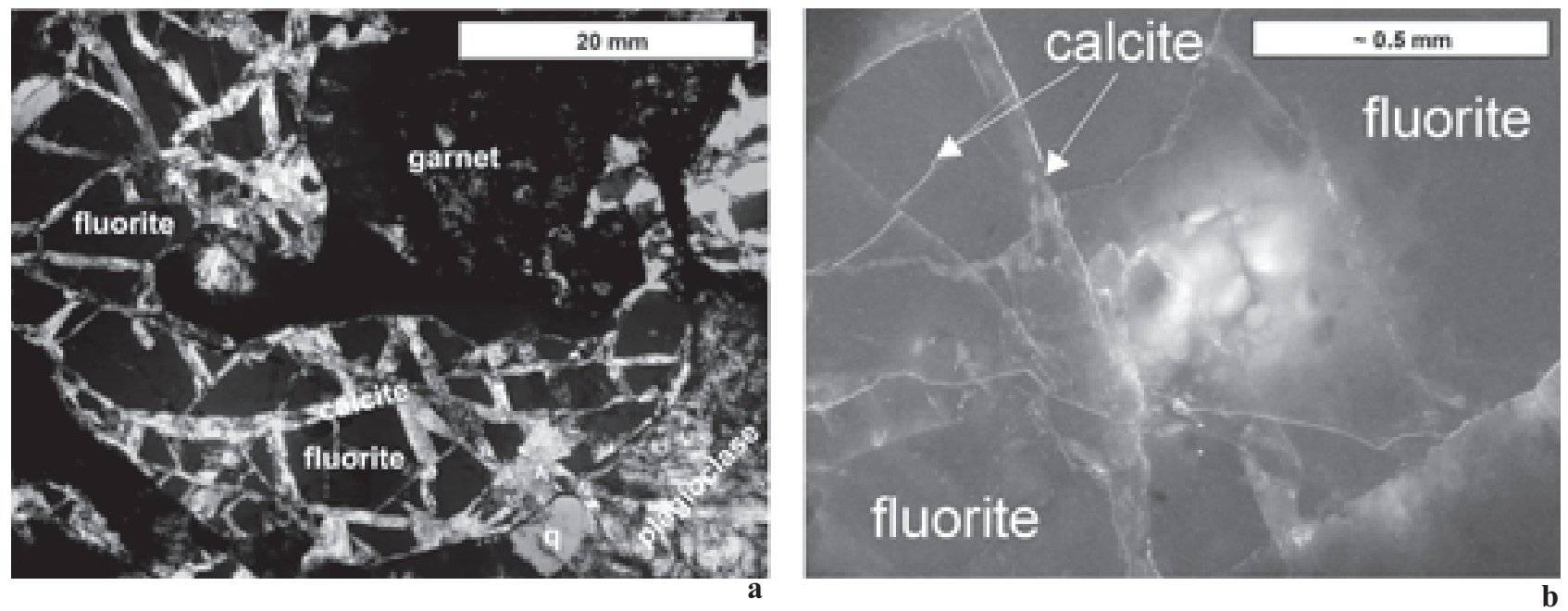

Fig. 2. a - Photomicrograph of strongly brecciated fluorite; $b$ - Cathodoluminiscence of fluorite with diffusion core. 
Table 1. Analyses of REE in fluorites from pegmatites at Vlastějovice

\begin{tabular}{|c|c|c|c|c|c|c|c|c|c|c|c|c|c|}
\hline Sample type & $1 * *$ & 1 & 1 & 1 & 1 & 1 & 1 & 1 & 1 & 1 & $2 * *$ & 2 & 2 \\
\hline La & 1.10 & 4.28 & 16.80 & 20.60 & 58.90 & 84.70 & 15.90 & 28.90 & 10.50 & 49.90 & 1.44 & 2.49 & 1.57 \\
\hline $\mathrm{Ce}$ & 3.28 & 6.77 & 17.80 & 32.86 & 147.90 & 273.20 & 13.08 & 39.75 & 12.16 & 126.30 & 2.01 & 3.48 & 1.95 \\
\hline Pr & - & - & - & - & - & - & - & - & - & - & - & - & - \\
\hline Nd & 3.90 & 3.80 & 14.20 & 20.60 & 65.90 & 69.60 & 13.90 & 22.00 & 8.50 & 38.10 & 1.49 & 1.47 & 0.77 \\
\hline Sm & 2.08 & 1.37 & 4.09 & 4.95 & 13.39 & 13.97 & 2.95 & 4.20 & 2.13 & 7.28 & 0.20 & 0.36 & 0.22 \\
\hline $\mathbf{E u}$ & 0.24 & 0.14 & 0.35 & 0.41 & 1.02 & 1.00 & 0.29 & 0.35 & 0.23 & 0.52 & 0.13 & 0.33 & 0.13 \\
\hline Gd & 4.33 & 2.21 & 3.88 & 3.94 & 9.52 & 10.98 & 2.76 & 3.07 & 3.00 & 6.09 & 0.11 & 0.35 & 0.25 \\
\hline $\mathbf{T b}$ & 1.21 & 0.53 & 0.72 & 0.77 & 1.31 & 1.56 & 0.81 & 0.75 & 0.75 & 0.99 & 0.03 & 0.05 & 0.02 \\
\hline Dy & - & - & - & - & - & - & - & - & - & - & - & - & - \\
\hline Ho & 3.46 & 1.26 & 1.37 & 1.20 & 1.37 & 1.76 & 1.76 & 1.39 & 1.82 & 1.71 & - & - & - \\
\hline $\mathbf{E r}$ & - & - & - & - & - & - & - & - & - & - & - & - & - \\
\hline Tm & - & - & 0.51 & - & - & - & - & - & 0.77 & 0.88 & - & - & - \\
\hline $\mathbf{Y b}$ & 9.91 & 4.30 & 3.89 & 3.86 & 4.15 & 6.05 & 7.19 & 5.24 & 6.70 & 5.54 & 0.02 & 0.05 & 0.02 \\
\hline Lu & 1.65 & 0.73 & 0.60 & 0.54 & 0.56 & 0.85 & 1.12 & 0.76 & 1.11 & 0.91 & 0.01 & 0.00 & 0.00 \\
\hline$\sum \mathrm{REE}$ & 31.17 & 25.39 & 64.21 & 89.73 & 304.02 & 463.67 & 59.76 & 106.41 & 47.66 & 238.21 & 5.43 & 8.57 & 4.93 \\
\hline $\mathrm{Tb} / \mathrm{La}$ & 1.10 & 0.12 & 0.04 & 0.04 & 0.02 & 0.02 & 0.05 & 0.03 & 0.07 & 0.02 & 0.02 & 0.02 & 0.02 \\
\hline $\mathbf{L a} / \mathbf{Y b}$ & 0.11 & 1.00 & 4.32 & 5.34 & 14.19 & 14.00 & 2.21 & 5.52 & 1.57 & 9.01 & 62.61 & 50.71 & 82.63 \\
\hline $\mathrm{Ce} / \mathrm{Ce}^{*}$ & 0.57 & 0.80 & 0.59 & 0.89 & 1.42 & 1.96 & 0.49 & 0.86 & 0.67 & 1.58 & 0.88 & 0.87 & 0.78 \\
\hline $\mathbf{E u} / \mathbf{E u}$ * & 0.18 & 0.21 & 0.26 & 0.27 & 0.29 & 0.26 & 0.24 & 0.25 & 0.23 & 0.24 & 2.36 & 3.13 & 2.24 \\
\hline
\end{tabular}

** 1, 2 samples from central zones and contact zones, respectively

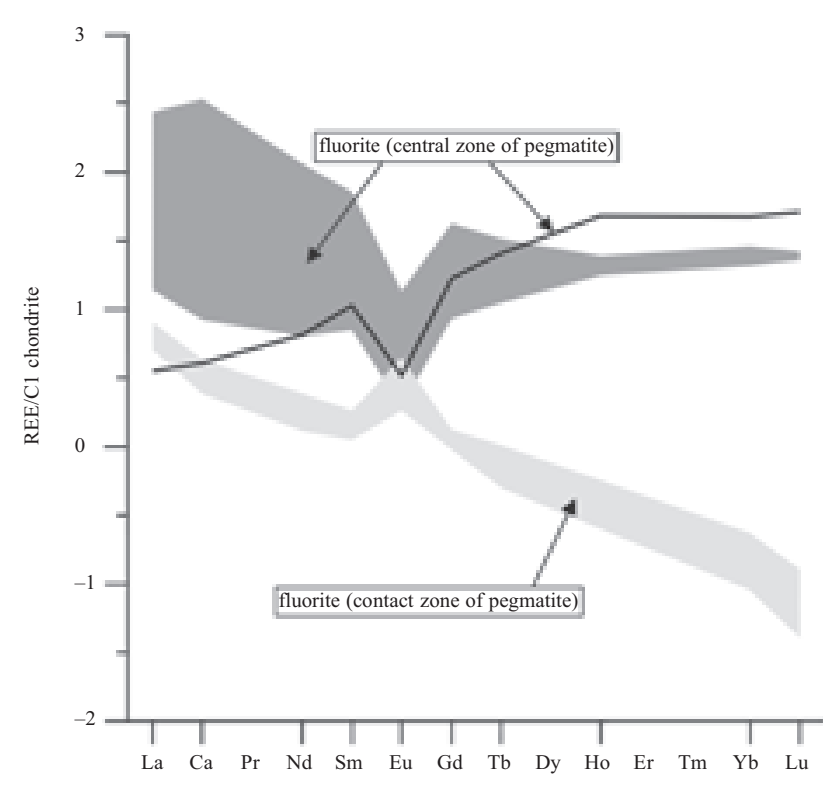

Fig. 3. REE distribution of fluorites.

stage fluorite tends to be Tb-rich with higher $\mathrm{Tb} / \mathrm{La}$ (Constantopoulos 1988, Salem et al. 2001). However, Tb/La ratios of fluorites from central zones and reaction zones of pegmatites are quite constant: $0.02-1.1$ and 0.02 , respectively,

$\mathrm{Ce} / \mathrm{Ce}^{*}$ and $\mathrm{Eu} / \mathrm{Eu}^{*}$ ratios (Table 1 ) were calculated as an estimate of the magnitude of the $\mathrm{Ce}$ and $\mathrm{Eu}$ anomalies $\left(\mathrm{REE} / \mathrm{REE}^{*}=\right.$ chondrite-normalized REE divided by REE*, which is the REE value extrapolated from the chondrite-normalized values for $\mathrm{La}$ and $\mathrm{Sm}$ for $\mathrm{Ce}^{*}$ or $\mathrm{Sm}$ and $\mathrm{Tb}$ for $\mathrm{Eu}^{*}$ ). All but three samples from central zones of the pegmatites have a weak negative $\mathrm{Ce}$ anomalies suggesting high oxygen fugacities of the rocks (skarns?) equilibrated with hydrothermal fluids (Constantopoulos 1988). Fluorites from central zones of the pegmatites have strong negative Eu anomalies in contrast to fluorites from contact zones with a strong positive anomaly. Feldspars typically have positive Eu anomaly, but Eu can be carried to the fluorite site under the oxidizing conditions as a $\mathrm{Eu}^{3+}$, resulting in positive Eu anomaly of fluorites from contact zones (Constantopoulos 1988). The strong negative Eu anomaly of fluorites from the central zones indicates the presence of $\mathrm{Eu}^{2+}$, thus low oxygen fugacities within the pegmatites, or a strong partitioning of Eu to other minerals (e.g., feldspar or allanite).

Fluid inclusions

\section{Petrography}

Primary inclusions have not been observed in fluorite. However numerous fluid inclusion planes (FIP) of pseudosecondary polyphase aqueous-carbonic (FS1) and secondary two-phase (FS2) aqueous inclusions, 10 to $40 \mu \mathrm{m}$ in size, cross-cutting fluorite grains were found.

Type FS1: pseudosecondary aqueous-carbonic inclusions with variable degree of fill (FS1A: 0.6; FS1B: 0.95) and the final homogenization to the liquid. They contain up to 3 solid phases of variable morphology and size (Fig. 4a,b). All were identified as calcium carbonates (calcite) by the Raman spectroscopy, which also revealed the presence of a small amount of $\mathrm{CO}_{2}(<5 \mathrm{~mol}$. \%) in the gaseous phase, not detected by the microthermometry. No dissolution of these solid phases was observed during microthermometry up to $500{ }^{\circ} \mathrm{C}$.

Type FS2: secondary aqueous inclusions of variable irregular shape, constant degree of fill $(\sim 0.95)$ and homogenization to the liquid. 


\section{Microthermometry}

The pseudosecondary FS1 inclusions differ by the degree of fill resulting in their different microthermometric characteristics. FS1A: low-salinity high-temperature inclusions with $\mathrm{Tm}$ ice -0.3 to $-0.4{ }^{\circ} \mathrm{C}$ (salinity 0.5 to 0.7 wt. $\% \mathrm{NaCl}$ eq.) and Th-tot +308 to $+372{ }^{\circ} \mathrm{C}$ (to the liquid). FS1B: medium-salinity medium-temperature inclusions. Tm ice -3.8 to $-5.6{ }^{\circ} \mathrm{C}$ (salinity 6.2 to 8.7 wt. $\%$ $\mathrm{NaCl}$ eq.) and Th-tot +160 to $+220^{\circ} \mathrm{C}$ (to the liquid).

Secondary FS2 inclusions represent low-salinity, lowtemperature fluids: Tm ice -0.1 to $-0.15^{\circ} \mathrm{C}$ (salinity 0.2 to 0.3 wt. $\% \mathrm{NaCl}$ eq.) and $\mathrm{Th}$-tot +102 to $+156{ }^{\circ} \mathrm{C}$ (to the liquid).

\section{Discussion}

Fluorite is very abundant in the barren and U-Th pegmatites with reaction zones, but very rare in the lithiumbearing pegmatite without reaction zones. This situation indicates a strong correlation between contamination processes (and the presence of garnet and hornblende in the reaction zones) and fluorite abundancy. Thus, source of fluorine must be in the skarn bodies (probably garnets with F content, Žáček et al. 2003).

Fluorite is very homogeneous under polarized light and during cathodoluminiscence observation, without any growth zones, which are typical for hydrothermal fluorites from the Bohemian Massif (e.g., Dolníček - Slobodník 2001). Other arguments against the hypothesis of a simple hydrothermal origin are the absence of fluorite in other vein-type mineralizations and the absence of lowtemperature primary fluid inclusions, which were found in many baryte-fluorite and fluorite vein-type mineralizations in the Bohemian Massif (e.g., Moldava, Jílové - see Dolníček - Slobodník 2001, Žák et al. 1990).

Different REE patterns of the fluorites from the central and contact zones of pegmatites and textural signs (e.g., irregular shapes of grains, presence of fluorite inclusions in other minerals) are the main arguments for the magmatic hypothesis of fluorite crystallization. On the other hand, experimental work shows a low solubility of fluorine in granitic melts (up to 2 wt. \%; D. Dolejš and M. Štemprok, pers. comm.). Thus, assuming extremely fluorine-rich granitic melts, as indicated by abundant fluorite in contact zones of pegmatites, some segregation (liquation) of fluorine-rich and silicate melt would be expected. There are no signs for a segregation and this type of liquation is strongly improbable under the assumed temperature of pegmatite crystallization (550$640{ }^{\circ} \mathrm{C}$ ) (D. Dolejš, pers. comm.).

Magmatic fluids of the barren pegmatites are represented by primary aqueous-carbonic inclusions in quartz, which homogenized at $410-440{ }^{\circ} \mathrm{C}$ (Ackerman 2004). High homogenization temperatures and the presence of $\mathrm{CO}_{2}$ in the gaseous phase of pseudosecondary inclusions in fluorite (FS1A) suggest, that these might represent
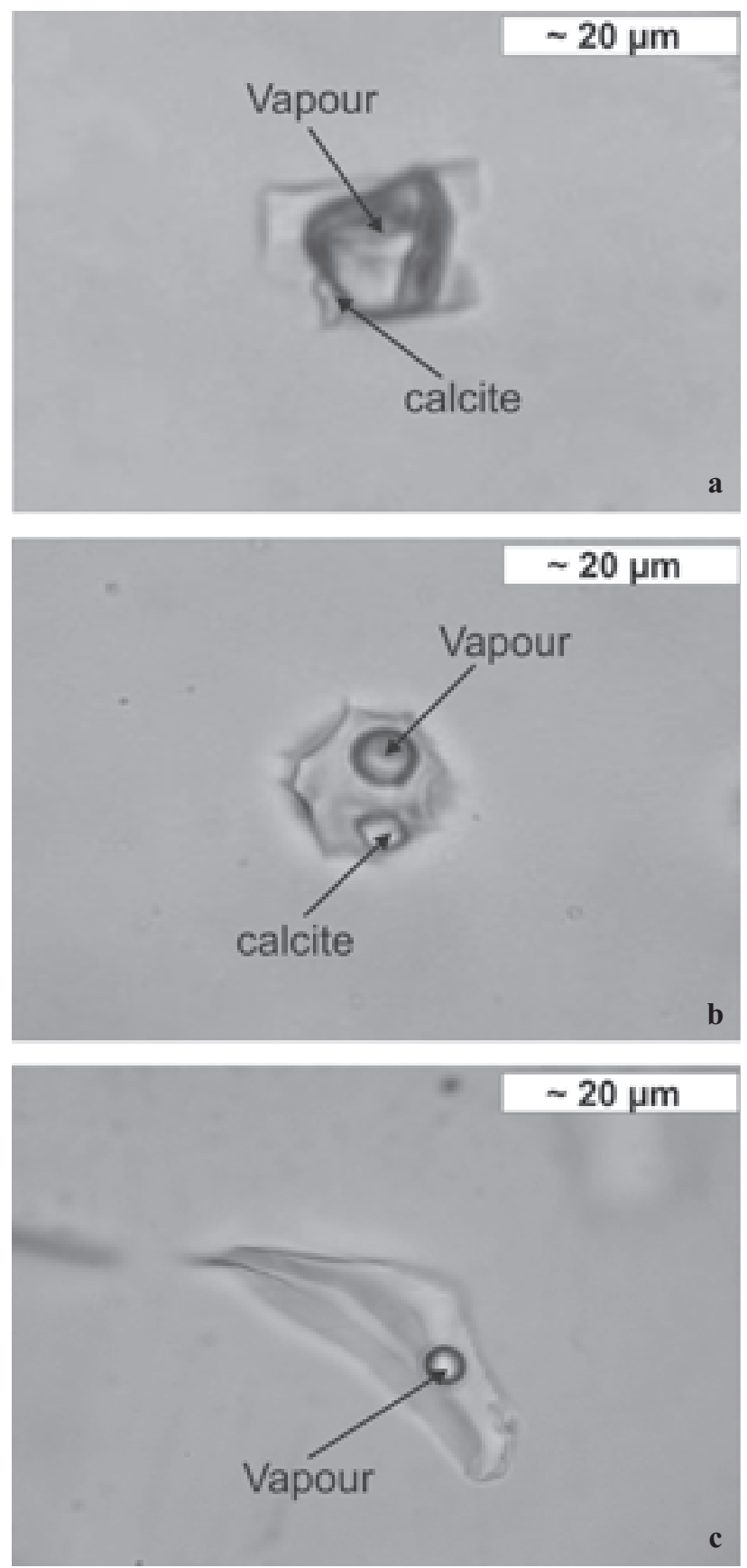

Fig. 4. Photomicrographs of fluid inclusions in fluorite; a - pseudosecondary $\mathrm{H}_{2} \mathrm{O}-\mathrm{CO}_{2}$ inclusion ( $\mathrm{FS} 1 \mathrm{~A}$ ); $\mathrm{b}$ - pseudosecondary $\mathrm{H}_{2} \mathrm{O}-\mathrm{CO}_{2}$ inclusion (FS1B); $\mathrm{c}-$ secondary $\mathrm{H}_{2} \mathrm{O}$ inclusion (FS2).

evolved magmatic fluids saturated by calcium $\left(\mathrm{CO}_{2}\right.$ loss $\rightarrow$ precipitation of calcite) at the pegmatite margins during the contamination processes. Similar fluids, but with lower homogenization temperatures (FS1B), probably represent a final evolution member of the magmatic fluids.

\section{Conclusions}

The crystallization of fluorites in Vlastějovice pegmatites was associated with contamination processes of the barren pegmatites by the skarn country-rock. Strong reaction 
zones along the pegmatites margins were formed following inflow of calcium- and fluorine-rich fluids from skarn. The fluorites associated with other fluorine bearing minerals (e.g., garnet, hornblende and titanite) were formed during late stages of pegmatite consolidation.

Minimal temperature of fluorite origin can be estimated from homogenization temperatures of pseudosecondary fluid inclusions (FS1A) found in fluorite (308$372{ }^{\circ} \mathrm{C}$ ). High temperatures suggest fluorite crystallization at magmatic-hydrothermal transition conditions.

Acknowledgments. This research was supported by the Grant Agency of the Czech Republic, project No. 205/ /00/D039, and by the Grant of the Ministry Education to the Faculty of Science, Charles University CEZ: J13/ /98:113100005. The author thank Jiří Zachariáš (Faculty of Science, Praha) for critical comments, Louis Raimbault (Ecole des Mines de Paris, France) and Milan Novák (Department of Earth Sciences, Brno) for trace-element analyses of fluorites and Stanislav Vrána (Czech Geological Survey, Praha) for review of the manuscript.

Submitted February 21, 2005

\section{References}

Ackerman, L. (2004): Pegmatity ve Vlastějovicích. - MS unpublished MSc. Thesis, Charles University, Prague, 86 pp. (in Czech with English summary)

Ackerman, L. - Zachariáš, J. - Pudilová, M. (2005): P-T conditions and fluid composition of barren and lithium pegmatites from Vlastějovice, Bohemian Massif, Czech Republic. - Int. J. Earth Sci., submitt.

Bernard, J. H. (1991): Empirical types of ore mineralizations in the Bohemian Massif. - Geological Survey, Prague, 181 pp.

Bodnar, R. J. (1993): Revised equation and table for determining the freezing point depression of $\mathrm{H}_{2} \mathrm{O}-\mathrm{NaCl}$ solutions. - Geochim. Cosmochim. Acta, 57: 683-684.

Brabec, P. (2002): Antimonová mineralizace ve Vlastějovicích. - MS unpublished MSc. Thesis, Charles University, Prague, 128 pp. (in Czech with English summary)

Constantopoulos, J. (1988): Fluid inclusions and rare earth elements geochemistry of fluorite from South-Central Idaho. - Econ. Geol., 83: 626-636.

Chrt, J. (1988): Barytová mineralizace Českého Masivu - Geol. Průzk., 30: 65-68. (in Czech)

Čech, F. (1985): Mineralogie žulových pegmatitů české části Českého Masívu. - MS unpublished D. Sc. Thesis, Charles University, Prague, 250 pp. (in Czech).

Dolniček, Z. - Slobodnik, M. (2001): The neoidic fluorite mineralization in the Brno Massif: Interaction between fluid and rock. - Geolines, 13: 51-52.

Kämpf, H. - Kuschka, E. (1989): Deposition related with stages of lateHercynian taphrogenetic evolution, Fluorobaritic deposition. - In: Tischendorf, G. (ed.): Silicic magmatism and metallogenesis of the Erzgebirge. Veroff. Zentralinstitut Physik der Erde, Potsdam, 107, 154-177.
Klečka, M. - Machart, J. - Pivec, E. (1992): Locality No. 10: Křížovská hora quarry near Vlašim, a Pre-Variscan tourmaline-bearing orthogneiss (Blaník type). - Field Trip Guidebook, Lepidolite 200, Nové Město na Moravě, June 1992, 69-74.

Koutek, J. (1950): Ložisko magnetovce skarnového typu u Vlastějovic v Posázaví. - Rozpr. Čs. Akad. Věd, Ř. mat. přír. Věd, 60: 27.

Mrázek, Z. - Vrána, S. (1984): Highly aluminian titanite at Vlastějovice, Czechoslovakia. - N. Jb. Mineral. Mh.: 193-196.

Němec, D. (1996): A discussion of geochemistry of regionally metamorphosed skarns of the Krušné Hory Mountains, Czech Republic, and implication for their genesis. - J. Czech Geol. Soc., 41: 23-31.

Novák, M. - Černý, P. (1998): Scandium in columbite-group minerals from LCT pegmatites in the Moldanubicum, Czech Republic. Krystalinikum, 24: 73-89.

Novák, M. - Povondra, P. (1995): Elbaite pegmatites in the Moldanubicum: A new subtype of the rare-element class. - Mineral. Petrol., 55: 159176.

Ogola, J. S. - Behr, H. J. - Kerkhof, van den. (1994): Fluid inclusion and cathodoluminis-cence studies on fluorite from Kerio valley, Kenya. Jour. Afr. Earth Sci., 4: 309-323.

Pertold, Z. - Pertoldová, J. - Pudilová, M. (1997): Metamorphic history of skarns in the Gföhl unit, Moldanubicum, Bohemian Massif, and implication for their origin. - Acta Univ. Carol., Geol., 41: 157-166.

Potužák, M. (1996): Skarn ve Vlastějovicích na Holém vrchu. - MS unpublished MSc. Thesis, Charles University, Prague, 138 pp. (in Czech with English summary)

Rezek, K. - Kryst, P. (1985): Předběžná zpráva o výskytu nerostů U-Th, Ti-Zr a Nb-Ta v pegmatitu na Holém vrchu u Vlastějovic, zsz. od Ledče nad Sázavou. - Čas. Miner. Geol., 30: 434. (in Czech)

Roedder, E. (1984): Fluid inclusions: Rev. Mineral. - Mineral. Soc. America, 12, Blackburg, 646 pp.

Salem, I. A. - Abdal-Moneum, A. A. - Shazly, A. G. - El-Shibiny, N. H. (2001): Mineralogy and geochemistry of Gabal El-Ineigi Granite and associated fluorite veins, Central Eastern Desert, Egypt: application of fluid inclusions to fluorite genesis. - Jour. Afr. Earth Sci., 32: 29-45.

Staněk, J. (1976): Pegmatites from Skarn near Líšná, Western Moravia. Acta Univ. Carol., Geol., 1-2: 145-149.

Vavřin, I. (1960): Pegmatity na magdalenském skarnovém ložisku. - MS unpublished MSc. Thesis, Charles University, Prague, 82 pp. (in Czech)

- (1962): Pegmatity magdalenského skarnového ložiska u Vlastějovic nad Sázavou. - Sbor. Nár. Muz., 18: 89-105. (in Czech)

Žáček, V. (1985): Mineralogie skarnu u Vlastějovic. - MS unpublished MSc. Thesis, Charles University, Prague, 160 pp. (in Czech)

- (1997): Compositional evolution of garnet in regionally metamorphosed Moldanubian skarn, Vlastějovice, Bohemia - evidence of the preservation of early stages pre-dating regional metamorphism. - Věst. Čes. Geol. Úst., 72: 37-48.

Žáček, V. - Novák, M. - Raimboult, L. - Zachariáš, J. - Ackerman, L. (2003): Locality No. 8: Vlastějovice near Zruč nad Sázavou. - Field Trip Guidebook, LERM 2003, Nové Město na Moravě, June 2003, 61-70.

Žáček, V. - Povondra, P. (1991): Krystalochemie minerálů skarnu z Vlastějovic nad Sázavou. - Acta Univ. Carol., Geol., 1-2: 71-101.

Žák, K. - Čadek, J. -Době̌, P. - Šmejkal, V.-Reichmann, F. -Vokurka, K. - Sandstat, J. S. (1990): Vein barite mineralization of the Bohemian Massif: Sulfur, oxygen and strontium isotopes and fluid inclusion characteristics and their genetic implications. - In: Poole, F. G. Dobeš, P. (eds): Proceedings of the Symposium on Barite and Barite Deposits. Symposium on Barite and Barite Deposits. Geol. Surv, Prague, 35-49. 


\section{Magmatický vs. hydrotermální vznik fluoritů z Vlastějovic, Český masiv}

Na lokalitě Vlastějovice (moldanubikum, Český masiv) byla studována fluoritová mineralizace v pegmatitech, které intrudovaly do skarnu. Na základě studia texturních charakteristik, katodové luminiscence a fluidních inkluzí je diskutován magmatický vs. hydrotermální původ fluoritů. Fluorit se převážně vyskytuje ve velkém množství spolu s granátem a amfibolem v reakčních (kontaktních) zonách pegmatitů, které vznikly v důsledku kontaminace pegmatitových tavenin skarnovým materiálem za př́nosu vápníku a fluóru. Mikroskopické studium a katodová lumiscence ukázaly velkou texturní homogenitu fluoritu bez náznaku jakékoliv zonálnosti. Obsahy vzácných zemin se výrazně liší u fluoritů z centrálních zón oproti fluoritům z kontaktních zón (silně ochuzeny o těžké vzácné zeminy). Pseudosekundární fluidní inkluze nalezené ve fluoritech, pravděpodobně představují původní primární magmatická fluida pegmatitů, která byla nasycena vápníkem v důsledku kontaminace. Minimální teplota vzniku fluoritů byla odhadnuta z teplot homogenizací těchto pseudosekundárních inkluzí $\left(308-372{ }^{\circ} \mathrm{C}\right)$. Na základě těchto aspektů lze soudit, že fluority pravděpodobně vznikly během závěrečných fází konsolidace pegmatitů na rozhraní magmatických-hydrotermálních podmínek. 
